\title{
Rhizospheric Fungal Diversities and Soil Biochemical Factors of Fritillaria taipaiensis over Five Cultivation Years
}

\author{
Nong Zhou ${ }^{1,2}$, Maojun $\mathrm{Mu}^{2}$, Hui Xie ${ }^{1}$, Yu Wu ${ }^{1}$, You Zhou ${ }^{2, *}$ and Weidong $\mathrm{Li}^{1, *}$ \\ 1 Jiangsu Key Laboratory of Chinese Medicine Processing, Engineering Center of State Ministry of Education \\ for Standardization of Chinese Medicine Processing, Nanjing University of Chinese Medicine, \\ Nanjing 210023, China; erhaizn@126.com (N.Z.); xhcarrie@163.com (H.X.); wylucky@njcm.edu.cn (Y.W.) \\ 2 The Chongqing Engineering Laboratory for Green Cultivation and Deep Processing of Three Gorges \\ Reservoir Area's Medicinal Herbs, College of Food and Biology Engineering, Chongqing Three Gorges \\ University, Chongqing 404120, China; 18780118293@163.com \\ * Correspondence: 20170013@sanxiau.edu.cn (Y.Z.); liweidong@njucm.edu.cn (W.L.)
}

Citation: Zhou, N.; Mu, M.; Xie, H.; Wu, Y.; Zhou, Y.; Li, W. Rhizospheric Fungal Diversities and Soil Biochemical Factors of Fritillaria taipaiensis over Five Cultivation Years. Horticulturae 2021, 7, 560. https:// doi.org/10.3390/horticulturae7120560

Academic Editors: George W. Bird and Koon-Hui Wang

Received: 8 November 2021

Accepted: 1 December 2021

Published: 8 December 2021

Publisher's Note: MDPI stays neutral with regard to jurisdictional claims in published maps and institutional affiliations.

Copyright: (c) 2021 by the authors. Licensee MDPI, Basel, Switzerland. This article is an open access article distributed under the terms and conditions of the Creative Commons Attribution (CC BY) license (https:// creativecommons.org/licenses/by/ $4.0 /)$.

\begin{abstract}
Fritillaria taipaiensis is a valuable traditional Chinese medicinal plant that has experienced continuous decline over its cropping area. The present study aims to explore the reasons for the quality and growth decline. The fungal diversities and biochemical factors in its rhizospheric soils with cultivation duration from 1 up to 5 years were analyzed and compared. The results showed that rhizospheric fungi of F. taipaiensis belong to six phyla, including Neocallimastigomycota, Glomeromycota, Basidiomycota, Chytridiomycota, Zygomycota and Ascomycota. Thirteen genera (Pseudogymnoascus, Fusarium, Mortierella, Colletotrichum, Laetinaevia, Gibberella, Synchytrium, Lysurus, Trichocladium, Volutella, Monoblepharis, Aquamyces and Trichoderma) constituted the "core community" in the rhizosphere of $F$. taipaiensis. The dominant fungal genera varied significantly in rhizospheric soils with different cultivation years. The abundance of fungal species in the soil declined with the cultivation year generally. The $\mathrm{pH}$, available $\mathrm{P}$, organic matter and urease activity were the primary factors determining the fungal community composition in the rhizosphere. The content of organic matter, available N, P and K and the activities of urease and alkaline phosphatase decreased with cultivation years. The soil $\mathrm{pH}$ increased with cultivation years and was unsuitable for $F$. taipaiensis growth. These features suggested that long-term single planting altered the fungal community structure, fertility conditions and soil enzyme activities in F. taipaiensis rhizospheric soils, which could be detrimental for plant growth and quality.
\end{abstract}

Keywords: Fritillaria taipaiensis; rhizospheric fungi; soil biochemical factors; long term single planting

\section{Introduction}

Fritillaria taipaiensis is a perennial herb in the family Liliaceae. Its bulbs contain multiple compounds, including alkaloids, steroids, terpenoids, purines and fatty acids, which can decrease the body temperature in human, relieve coughing and asthma and resolve phlegm [1-3]. There is no apparent difference in the alkaloid types between F. taipaiensis and F. cirrhosa (Chuan BeiMu), which is a precious traditional Chinese medicinal material [4].

Therefore, F. taipaiensis has a significant economic value and has been collected in a national standard for traditional Chinese medicine as one of the medical material provenances of Chuan BeiMu in 2015 [5]. In recent years, studies have been carried out on the suitable community types and production areas of F. taipaiensis [6,7] as well as on the ecological factors, such as growth temperature, relative air humidity, sunshine log and soil condition, which affect the growth of F. taipaiensis [8].

Researchers identified the suitable production areas of F. taipaiensis and conducted cropping to expand its production in suitable areas. However, the seedlings of F. taipaiensis have demonstrated problems of germplasm degradation, such as growth potential reduc- 
tion [9], disease accumulation [10] and quality decline [11] after 3-4 years of continuous cultivation, which negatively affect its production.

The interaction between soil microbial and biochemical properties plays a major role in the degradation of soil organic matter and soil nutrient cycling [12,13]. The soil quality could be indicated by the soil enzyme activities and microbial community composition $[13,14]$. Recent studies suggested that continuous cropping and long-term single planting patterns cause imbalances in the soil microbial community diversity and structure [15-17].

In addition, fungal pathogens that accumulate in continuous cropping and long-term single planting could also affect the growth of plants adversely [18-21]. However, current studies are focused on the issue of germplasm degradation in F. taipaiensis with respect to fertilization control and improvement in the planting technology [22,23]. Conversely, studies on the effects of rhizospheric microorganisms to explore the problems of growth and quality decline during the $F$. taipaiensis cultivation have not progressed satisfactorily.

This study aims to explore the reasons for quality and growth decline of cultivated F. taipaiensis. Therefore, the fungal structural composition and biochemical factor characteristics of the rhizospheric soils in which F. taipaiensis was planted for 1-5 years were compared and analyzed. The results of this study could provide a theoretical basis for the sustainable cultivation of F. taipaiensis.

\section{Materials and Methods}

\subsection{Experimental Site Location}

Sampling was conducted in Lanying Village, Wuxi County, Chongqing, China $\left(31^{\circ} 23^{\prime} 56.11^{\prime \prime} \mathrm{N}\right.$, $109^{\circ} 50^{\prime} 29.93^{\prime \prime} \mathrm{E}-31^{\circ} 35^{\prime} 26.57^{\prime \prime} \mathrm{N}, 109^{\circ} 00^{\prime} 11.96^{\prime \prime} \mathrm{E}$; $2274-2290 \mathrm{~m}$ above sea level), with an annual average temperature of $7.2^{\circ} \mathrm{C}$ and an annual average precipitation of 1100-1300 $\mathrm{mm}$ [9]. The soil at the study site was classified as yellow-brown mountain soil (fine-loamy, mixed, mesic Aridic Haplustalf). The experimental plots were located in a field established in 2008 that had been cropped continuously. The field was $20 \times 20 \mathrm{~m}$ for F. taipaiensis with each cultivation year, and the fields were natural wastelands with the same soil basement condition before planting. The fertilization of the field was N-P-K 15:15:15 (M/M), $225 \mathrm{~kg} \cdot \mathrm{hm}^{-2}$ for each year.

\subsection{Sample Collection}

In May, 2017. F. taipaiensis rhizospheric soils (6-10 cm below the ground) with different cultivation years from 1 to 5 (Y1, Y2, Y3, Y4 and Y5) were sampled from three sample plots $(3 \times 3 \mathrm{~m})$ randomly selected in the field by the multiple mixture sampling method [24]. The soils were collected by the shaking root method [24] and then were placed into the aseptic bags in ice box transferred into laboratory after removing the litters and residual cover. Three parallel soil samples were taken for each experimental sample and then were sifted by a $2 \mathrm{~mm}$ sieve, divided into two parts, of which one was ground to be used for the soil physical-chemical analysis after room temperature air drying, while the other one was stored in an $-80^{\circ} \mathrm{C}$ ultra-low temperature freezer after freeze drying to be used in soil total DNA extraction.

\subsection{Soil Biochemical Analysis}

Regarding soil chemical indicators, the $\mathrm{pH}$ was determined by a $\mathrm{pH}$ analyzer, the organic matter content was determined by potassium dichromate oxidation-outer heating, the available phosphorus content was determined by the anti-colorimetric method of molybdenum and antimony, the available nitrogen content was determined by the diffusion method [25], and the available potassium content was determined by ammonium acetateatomic absorption spectrometry [26].

Soil enzyme activities were determined as described previously [26]. The invertase activity was determined by 3,5-dinitrosalicylic acid colorimetric method, expressed in terms of the glucose content in $1 \mathrm{~g}$ dry soil $24 \mathrm{~h}$ after treatment. The protease activity 
was determined by ninhydrin colorimetry, expressed in terms of the amino acid content in $1 \mathrm{~g}$ dry soil $24 \mathrm{~h}$ after treatment. The urease activity was determined by the sodium chlorate-sodium phenol colorimetric method, expressed in terms of the amino nitrogen content in $1 \mathrm{~g}$ dry soil $24 \mathrm{~h}$ after treatment. The catalase activity was determined by pyrogallol colorimetry, expressed in terms of the theogallin content in $1 \mathrm{~g}$ dry soil $20 \mathrm{~min}$ after treatment. Both acid phosphatase and alkaline phosphatase activities were determined using the sodium phenylene phosphate colorimetric method, expressed in terms of the phenol content in $1 \mathrm{~g}$ dry soil $24 \mathrm{~h}$ after treatment.

\subsection{Soil DNA Extraction and High-Throughput Sequencing}

A Fritillaria taipaiensis rhizospheric soil sample $(0.25 \mathrm{~g})$ was used for DNA extraction by the CTAB method [27]. The genomic DNA was diluted to $1 \mathrm{ng} / \mu \mathrm{L}$ and amplified by PCR via high-fidelity DNA polymerase and Phusion ${ }^{\circledR}$ High-Fidelity PCR Master Mix with GC Buffer (New England Biolabs, Beijing, China) using specific primers, ITS5-1737F (5'GGAAGTAAAAGTCGTAACAAGG-3') and ITS2-2043R (5'-GCTGCGTTCTTCATCGATGC$3^{\prime}$ ), for the internal transcribed spacer fungal barcode region (ITS) [17]. The amplification reaction was as follows: pre-denaturation at $98{ }^{\circ} \mathrm{C}$ for $1 \mathrm{~min}, 30$ cycles of denaturation at $98{ }^{\circ} \mathrm{C}$ for $10 \mathrm{~s}$, annealing at $50{ }^{\circ} \mathrm{C}$ for $30 \mathrm{~s}$, extension at $72{ }^{\circ} \mathrm{C}$ for $1 \mathrm{~min}$, and extension at $72{ }^{\circ} \mathrm{C}$ for $5 \mathrm{~min}$. The PCR products were analyzed by $2 \%$ agarose gel electrophoresis and extracted by gel extraction kit (Qiagen, Hilden, Germany). The DNA library was constructed using TruSeq ${ }^{\circledR}$ DNA PCR-Free Sample Preparation Kit (Illumina, San Diego, CA, USA) and sequenced on the Illumina HiSeq platform.

\subsection{Data Analysis}

Raw forward and reverse sequence reads were assembled using FLASH (V1.2.7, http:/ /ccb.jhu.edu/software/FLASH/, 1 June 2021), which was further filtered and spiced through QIIME (V1.7.0, http:/ / qiime.org/scripts/split_libraries_fastq.html, 1 June 2021). Further, the chimeras in the clean data were eliminated by comparing with UCHIME (Algorithm, http:/ / www.drive5.com/usearch/manual/uchime_algo.html, 1 June 2021) and database (Unite database, https:/ / unite.ut.ee/, 1 June 2021) to obtain the effective tags. The depth of sequencing was 40,000 reads at least in each original library, and the operational taxonomic units (OTUs) were analyzed and clustered by using the UPARSE software (version 7.0.1090) based on 97\% similarity. According to the result of OTU clustering, the representative sequence of OTUs were annotated by a species by using QIIME (version 1.9.1). The relative abundance was analyzed via Mothur (version.1.44.0).

The Mothur software (version.1.44.0) was used to calculate the Goods-coverage, Chao1, ACE, Shannon, and Simpson indices. The QIIME software (version 1.9.1) was used to calculate the Unifrac distance and to plot the unweighted pair-group method using an arithmetic average (UPGMA) cluster tree. The R-software (version 2.15.3) was used to plot the rank abundance curve. Moreover, the relative abundance and the alpha diversity of OTUs were analyzed to obtain the information, such as the specific-species abundance in one sample and the common and specific OTUs among the different samples and groups by Tukey's test on R-software. The non-metric multidimensional scaling (NMDS), distance-based redundancy analysis (db-RDA) and Adonis were analyzed by vegan bag on R-software.

To study the difference among the alpha diversity indices, fungal taxonomic compositions and soil biochemical factors in the $F$. taipaiensis rhizospheric soils with different cultivation years and the effect of cultivation year on the core community, we applied the one-way ANOVA and the Duncan for variance analysis and multiple comparisons via SPSS 22.0 and Excel $2003(\alpha=0.05)$. 


\section{Results}

\subsection{Alpha Diversities of the Rhizospheric Soils with Different Cultivation Years}

The rank abundance curves were drawn according to the relative abundance of OTUs (Figure 1). The results showed the curve of the sample $Y 4$ had the maximum abscissa span and the softest changing trend in the ordinate, which indicated that $F$. taipaiensis rhizospheric soil with 4 years of cultivation had the maximum fungal species richness and evenness. Moreover, the curve of the sample Y5 had the minimum abscissa span and the maximum ordinate changing trend, indicating that rhizospheric soil with 5 years of cultivation had the minimum fungal species richness and evenness.

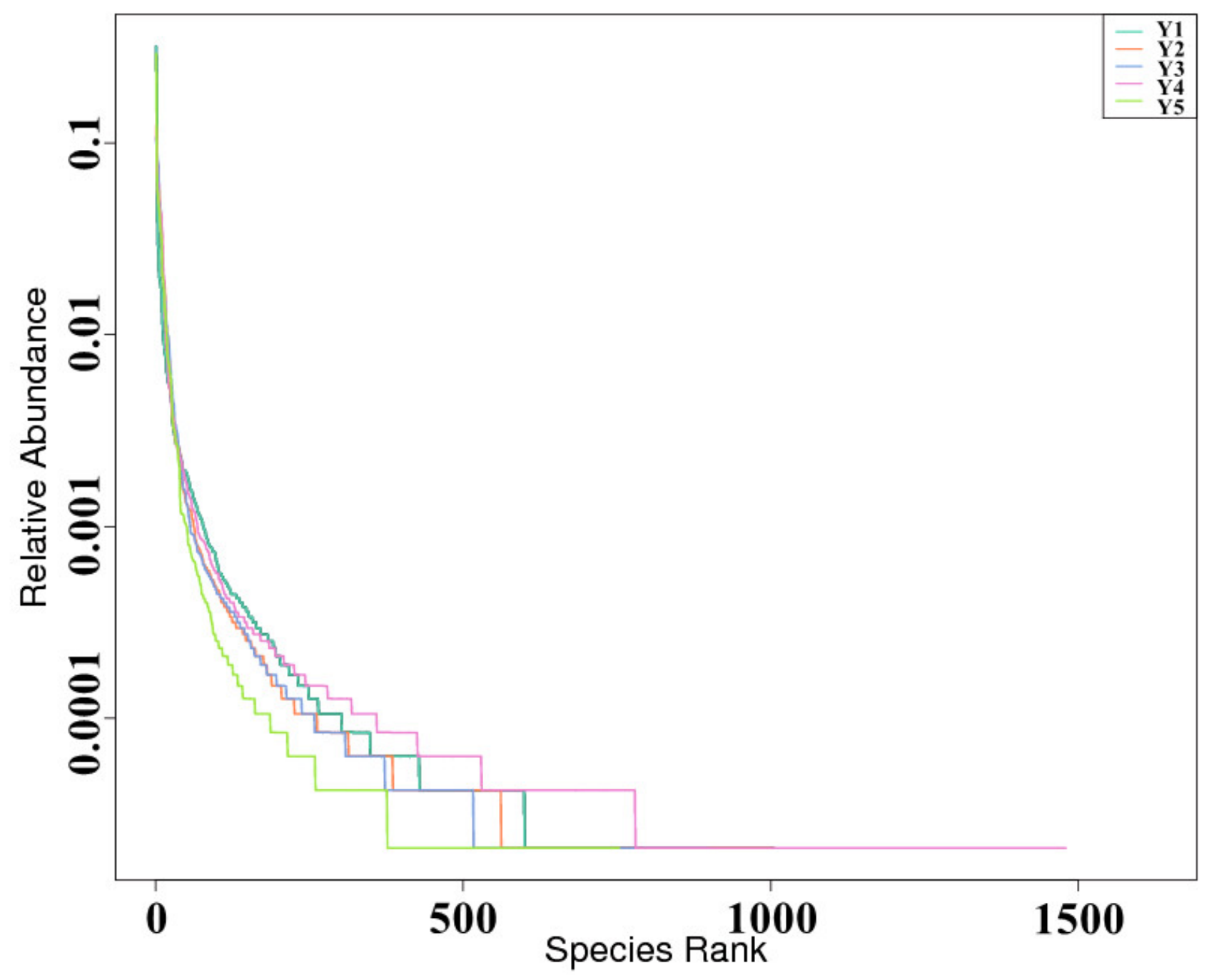

Figure 1. Rank abundance curve. Y1-Y5: F. taipaiensis rhizospheric soils with different cultivation years from 1 to 5; the abscissa represents the serial number of species sorted by the relative abundance, and the ordinate represents the relative abundance. In the horizontal direction, the wider the abscissa span, the higher the species richness; in the vertical direction, the smoother the curve, the higher the species evenness.

The alpha diversity indices are listed in Table 1 . The Goods_coverage indices indicated that the species coverage detected in each sample was $>99 \%$; no significant difference was detected in the Shannon and Simpson indices between the samples, which reflected that the species evenness in the samples with different cultivation years did not show any significant change. Moreover, the Chao1 and ACE indices varied significantly in samples, the sample Y4 having the highest Chao1 and ACE, whereas these parameters were significantly lower 
in the samples $Y 2$ and $Y 5$, indicating that the fungal species richness in the samples changed with the cultivation year.

Table 1. Alpha diversity indices of the rhizospheric fungal communities along five years of $F$. taipaiensis cultivation.

\begin{tabular}{cccccc}
\hline Sample & $\begin{array}{c}\text { Goods- } \\
\text { Coverage }\end{array}$ & Chao1 & ACE & Shannon & Simpson \\
\hline Y1 & $0.996 \mathrm{a}$ & $913.377 \mathrm{~b}$ & $936.699 \mathrm{~b}$ & $4.668 \mathrm{a}$ & $0.855 \mathrm{a}$ \\
Y2 & $0.998 \mathrm{a}$ & $692.037 \mathrm{c}$ & $698.812 \mathrm{c}$ & $5.172 \mathrm{a}$ & $0.937 \mathrm{a}$ \\
Y3 & $0.996 \mathrm{a}$ & $842.382 \mathrm{~b}$ & $851.813 \mathrm{~b}$ & $4.855 \mathrm{a}$ & $0.911 \mathrm{a}$ \\
Y4 & $0.995 \mathrm{a}$ & $1067.841 \mathrm{a}$ & $1069.508 \mathrm{a}$ & $5.156 \mathrm{a}$ & $0.916 \mathrm{a}$ \\
Y5 & $0.997 \mathrm{a}$ & $612.326 \mathrm{c}$ & $642.342 \mathrm{c}$ & $4.386 \mathrm{a}$ & $0.866 \mathrm{a}$ \\
\hline
\end{tabular}

Values followed by the same letter in the column do not differ significantly $(p<0.05)$. Y1-Y5: F. taipaiensis rhizospheric soils with different cultivation years from 1 to 5; Goods_coverage: indicator reflects the depth of sequencing, the closer the value is to 1 , the more reasonable the sequencing depth, indicating that the sequencing depth has covered all species in the sample; Chao1: provides an estimation of the actual number of OTUs in the sample as an indicator of species richness, the higher value means higher species richness; ACE: an indicator of species richness, the higher value means higher species richness, with a different algorithm to Chao1; Shannon: an index quantifies the entropy of the distribution, which depends on the evenness of the proportional abundances of OTUs in the population, the higher value means higher species evenness; and Simpson: an indicator of species evenness, the higher value means higher species evenness with a different algorithm to Shannon.

\subsection{Fungal Taxonomic Composition}

The fungal community in the rhizosphere of $F$. taipaiensis was mainly composed of Ascomycota, Zygomycota, Chytridiomycota, Basidiomycota, Glomeromycota, and Neocallimastigomycota. The dominant fungal phylum with the maximum relative abundance up to $68.23 \%$ was Ascomycota, and the relative abundance of Chytridiomycota showed a marked variation in different samples, which declined from $11.12 \%$ in $Y 1$ to $0.69 \%$ in $Y 3$ (Table 2).

Table 2. The relative abundance of fungal phyla in the samples with different cultivation years.

\begin{tabular}{cccccc}
\hline \multirow{2}{*}{ Phylum } & \multicolumn{5}{c}{ Relative Abundance (\%) } \\
\cline { 2 - 6 } & $\mathbf{Y 1}$ & Y2 & Y3 & Y4 & Y5 \\
\hline Ascomycota & $47.20 \mathrm{~d}$ & $68.23 \mathrm{a}$ & $65.86 \mathrm{a}$ & $58.23 \mathrm{~b}$ & $52.59 \mathrm{c}$ \\
Zygomycota & $36.60 \mathrm{a}$ & $18.46 \mathrm{c}$ & $27.76 \mathrm{~b}$ & $28.50 \mathrm{~b}$ & $39.30 \mathrm{a}$ \\
Chytridiomycota & $11.12 \mathrm{a}$ & $0.98 \mathrm{~b}$ & $0.69 \mathrm{c}$ & $0.96 \mathrm{~b}$ & $0.73 \mathrm{c}$ \\
Basidiomycota & $3.30 \mathrm{~d}$ & $11.68 \mathrm{a}$ & $4.82 \mathrm{c}$ & $7.28 \mathrm{~b}$ & $6.93 \mathrm{~b}$ \\
Glomeromycota & $1.61 \mathrm{~b}$ & $0.39 \mathrm{~d}$ & $0.66 \mathrm{c}$ & $2.71 \mathrm{a}$ & $0.34 \mathrm{~d}$ \\
Neocallimastigomycota & $0.03 \mathrm{a}$ & $0.01 \mathrm{~b}$ & $0.01 \mathrm{~b}$ & $0.01 \mathrm{~b}$ & $0.01 \mathrm{~b}$ \\
Others & $0.14 \mathrm{~d}$ & $0.25 \mathrm{~b}$ & $0.20 \mathrm{c}$ & $2.31 \mathrm{a}$ & $0.10 \mathrm{~d}$ \\
\hline
\end{tabular}

Values followed by the same letter in the column do not differ significantly $(p<0.05)$. Y1-Y5: F. taipaiensis rhizospheric soils with different cultivation years from 1 to 5 .

On the other hand, the samples with different cultivation years were clustered by the unweighted pair group method using the arithmetic average (UPGMA) (Figure 2). The samples $Y 2$ and $Y 3$ could be grouped, indicating that the samples with 2-3 cultivation years had similar fungal community structures. Moreover, the samples Y1, Y4 and Y5 could not be grouped in the same cluster as the other samples, which indicated the fungal community structures in F. taipaiensis rhizospheric soil changed significantly with the cultivation year and had a relatively stable period at the second and third cultivation years.

The fungal genera with the top 20 relative abundances in rhizospheric soil of F. taipaiensis were Aquamyces, Arthrobotrys, Colletotrichum, Fusarium, Gibberella, Heydenia, Ilyonectria, Laetinaevia, Lentinus, Lysurus, Microidium, Monoblepharis, Mortierella, Myrothecium, Peziza, Pseudogymnoascus, Synchytrium, Trichocladium, Trichoderma and Volutella (Table 3). The cultivation year increased the relative abundance of Mortierella, 
Microidium, Heydenia and Ilyonectria and decreased the relative abundance of Pseudogymnoascus, Synchytrium, Monoblepharis, Aquamyces and Trichoderma.

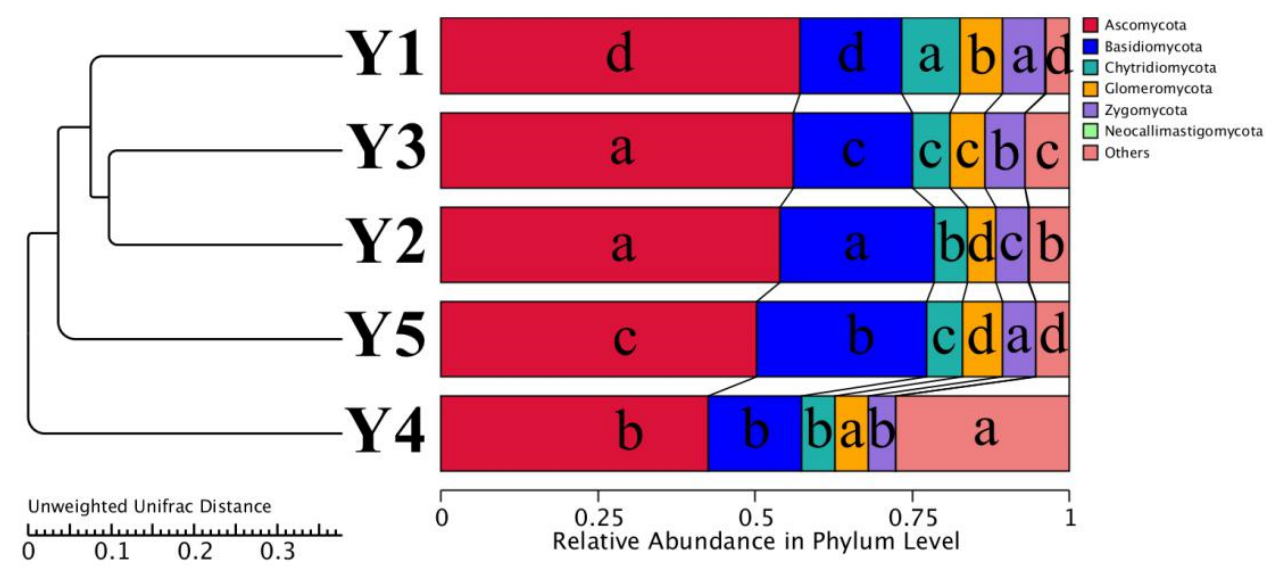

Figure 2. UPGMA dendrogram and relative abundance of main fungal phyla across sampling over years. Different lowercase letters indicate significant differences $(p<0.05)$ in the same phylum among five samples. Y1-Y5: F. taipaiensis rhizospheric soils with different cultivation years from 1 to 5 .

Table 3. Relative abundance of fungal genera in the samples with different cultivation years.

\begin{tabular}{lccccc}
\hline \multirow{2}{*}{ Genus } & \multicolumn{5}{c}{ Relative Abundance (\%) } \\
\cline { 2 - 6 } & $\mathbf{Y 1}$ & $\mathbf{Y}$ & $\mathbf{Y 3}$ & $\mathbf{Y 4}$ & $\mathbf{Y 5}$ \\
\hline Pseudogymnoascus & $18.26 \mathrm{a}$ & $6.69 \mathrm{~b}$ & $1.69 \mathrm{~d}$ & $0.23 \mathrm{e}$ & $4.02 \mathrm{c}$ \\
Fusarium & $4.74 \mathrm{~b}$ & $0.01 \mathrm{~d}$ & $9.63 \mathrm{a}$ & $0.69 \mathrm{c}$ & $0 \mathrm{~d}$ \\
Peziza & $0 \mathrm{e}$ & $9.05 \mathrm{a}$ & $0.03 \mathrm{~d}$ & $3.73 \mathrm{~b}$ & $0.23 \mathrm{c}$ \\
Mortierella & $0.37 \mathrm{e}$ & $3.79 \mathrm{c}$ & $1.21 \mathrm{~d}$ & $7.16 \mathrm{~b}$ & $9.76 \mathrm{a}$ \\
Arthrobotrys & $0 \mathrm{~d}$ & $0.04 \mathrm{c}$ & $0.26 \mathrm{~b}$ & $5.15 \mathrm{a}$ & $0 \mathrm{~d}$ \\
Colletotrichum & $0.04 \mathrm{~d}$ & $4.36 \mathrm{a}$ & $2.23 \mathrm{~b}$ & $0.18 \mathrm{c}$ & $0.05 \mathrm{~d}$ \\
Myrothecium & $0.04 \mathrm{~b}$ & $3.58 \mathrm{a}$ & $0.05 \mathrm{~b}$ & $0.02 \mathrm{c}$ & $0 \mathrm{~d}$ \\
Laetinaevia & $0.01 \mathrm{e}$ & $2.65 \mathrm{~b}$ & $0.06 \mathrm{~d}$ & $6.23 \mathrm{a}$ & $0.18 \mathrm{c}$ \\
Gibberella & $0.93 \mathrm{~b}$ & $0 \mathrm{~d}$ & $5.07 \mathrm{a}$ & $0.12 \mathrm{c}$ & $0 \mathrm{~d}$ \\
Microidium & $0.02 \mathrm{~d}$ & $0.04 \mathrm{c}$ & $0.06 \mathrm{c}$ & $0.27 \mathrm{~b}$ & $3.26 \mathrm{a}$ \\
Synchytrium & $4.99 \mathrm{a}$ & $0.14 \mathrm{~b}$ & $0.08 \mathrm{c}$ & $0.06 \mathrm{c}$ & $0.01 \mathrm{~d}$ \\
Lysurus & $0.14 \mathrm{~d}$ & $4.21 \mathrm{a}$ & $1.24 \mathrm{c}$ & $1.49 \mathrm{c}$ & $3.67 \mathrm{~b}$ \\
Trichocladium & $0.28 \mathrm{~d}$ & $1.19 \mathrm{~b}$ & $1.52 \mathrm{~b}$ & $2.61 \mathrm{a}$ & $0.79 \mathrm{c}$ \\
Volutella & $0.13 \mathrm{~d}$ & $0.81 \mathrm{c}$ & $1.90 \mathrm{~b}$ & $3.53 \mathrm{a}$ & $1.86 \mathrm{~b}$ \\
Monoblepharis & $2.03 \mathrm{a}$ & $0.01 \mathrm{~b}$ & $0.04 \mathrm{~b}$ & $0.02 \mathrm{~b}$ & $0.01 \mathrm{~b}$ \\
Lentinus & $0.01 \mathrm{~b}$ & $0.02 \mathrm{~b}$ & $0.99 \mathrm{a}$ & $0 \mathrm{c}$ & $0 \mathrm{c}$ \\
Heydenia & $0 \mathrm{~b}$ & $0 \mathrm{~b}$ & $0 \mathrm{~b}$ & $0 \mathrm{~b}$ & $2.07 \mathrm{a}$ \\
Aquamyces & $1.67 \mathrm{a}$ & $0.14 \mathrm{~b}$ & $0.13 \mathrm{~b}$ & $0.15 \mathrm{~b}$ & $0.04 \mathrm{c}$ \\
Trichoderma & $0.92 \mathrm{a}$ & $0.33 \mathrm{~b}$ & $0.15 \mathrm{c}$ & $0.05 \mathrm{~d}$ & $0.02 \mathrm{~d}$ \\
Ilyonectria & $0 \mathrm{~d}$ & $0.01 \mathrm{c}$ & $0.02 \mathrm{c}$ & $0.37 \mathrm{~b}$ & $0.71 \mathrm{a}$ \\
\hline Vat & & &
\end{tabular}

Values followed by the same letter in the column do not differ significantly $(p<0.05)$. Y1-Y5: F. taipaiensis rhizospheric soils with different cultivation years from 1 to 5 .

Fusarium, Gibberella and Lentinus had the highest relative abundance in sample Y3, and the relative abundance of Arthrobotrys, Laetinaevia, Trichocladium and Volutella in sample Y4 was significantly higher than those in the other samples. The relative abundance of Peziza, Colletotrichum, Myrothecium and Lysurus showed a declining trend after initial ascending with the cultivation year. Moreover, the relative abundance of Peziza, Arthrobotrys and Ilyonectria was absent in sample Y1 but became relatively high in the other samples. Heydenia was absent in samples Y1, Y2, Y3 and Y4 but had a relatively high abundance in $Y 5$. The results above showed that F. taipaiensis rhizospheric soils with different cultivation years had a significant difference in the dominant fungal community on the genus level. 
The heatmap of the fungal genera with the top 35 relative abundances in each sample showed that the dominant fungal genera were different between samples: in sample Y1, the dominant fungal genera were Nowakowskiella, Cladosporium, Aquamyces, Sarocladium, Synchytrium, Phialocephala, Batrachochytrium, Mariannaea, Monoblepharis, Pseudogymnoascus, Trichocladium and Crustoderma. In Y2, the genera were Monographella, Lysurus, Colletotrichum, Ustilago, Myrothecium, Mrakia, Hymenoscyphus, Peziza and Gonapodya. In Y3, the genera were Fusarium, Gibberella and Lentinus.

In Y4, the genera were Laetinaevia, Arthrobotrys, Stachybotrys, Volutella, Leucangium and Trichocladium, while in Y5, the genera were Heydenia, Thelebolus, Microidium, Mortierella and Ilyonectria (Figure 3a). As shown in the Venn diagram, the samples with different cultivation years shared 181 common OTUs, the numbers of unique OTUs in each sample from Y1-Y5 were 346, 248, 207, 879 and 209, respectively (Figure 3b), indicating that the sample $Y 4$ was greatly different from the other samples with respect to fungal community structures. Furthermore, the 181 common OTUs included 53 describable species in 46 genera (Table S1).

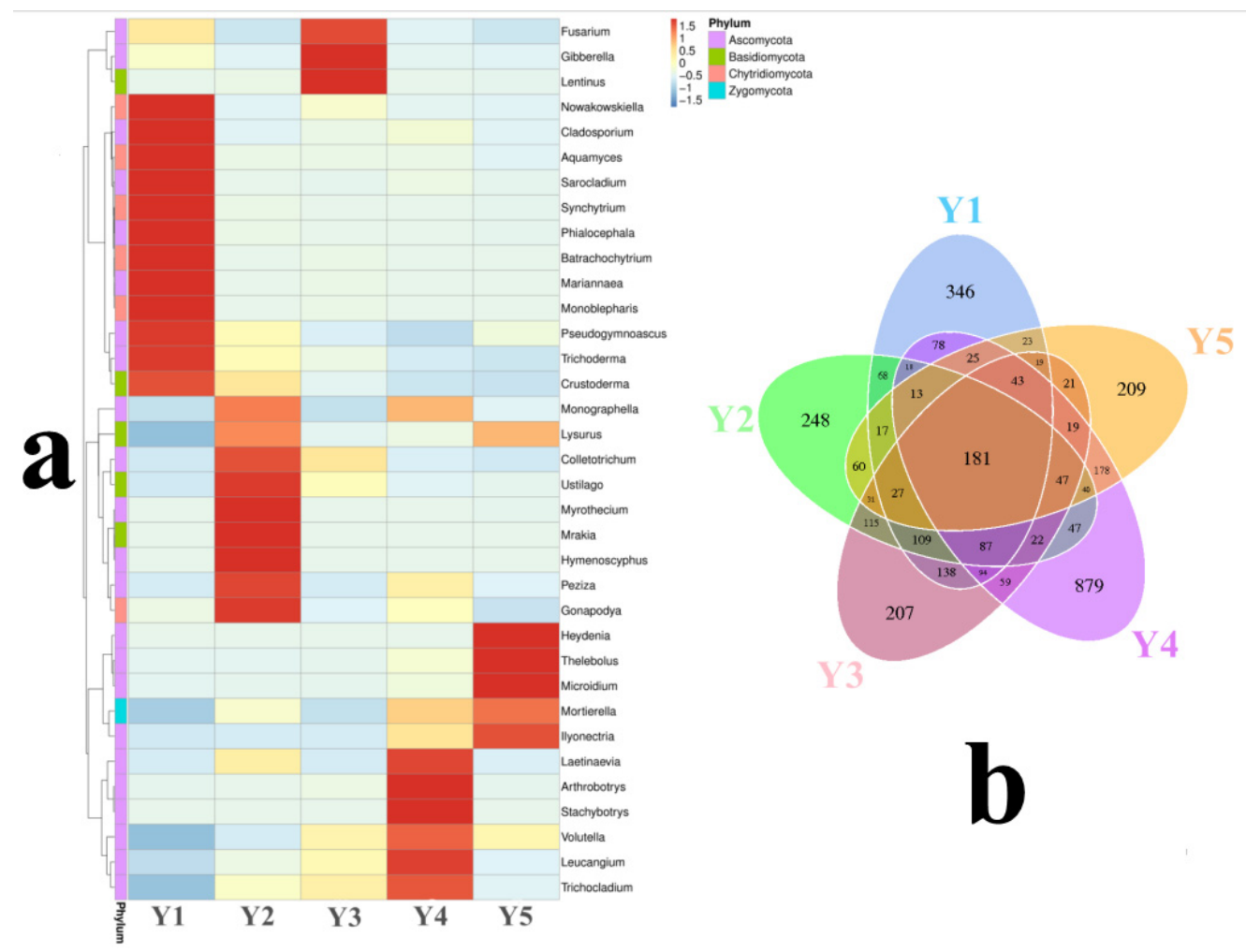

Figure 3. (a) Heatmap showing the relative abundance of the top 35 most abundant fungal genera in the samples over the years. The left side of (a) is a species clustering tree. The values corresponding to the heatmap are $Z$-values obtained by standardizing the relative abundance of the species in each row. The Z-value of the sample in a specific classification indicated the difference between the relative abundance of the sample and the average relative abundance of all samples divided by the standard deviation of all samples in the classification. (b) Venn diagram of the OTUs in the samples over years at $97 \%$ nucleotide sequence identity similarity, showing the common and unique OTU numbers in the samples. Y1-Y5: F. taipaiensis rhizospheric soils with different cultivation years from 1 to 5 .

Thirteen genera (Pseudogymnoascus, Fusarium, Mortierella, Colletotrichum, Laetinaevia, Gibberella, Synchytrium, Lysurus, Trichocladium, Volutella, Monoblepharis, Aquamyces and Trichoderma) of the common OTUs with high relative abundance could be considered as the "core community" in the rhizosphere of F. taipaiensis. For the core community, the effect of cultivation year on the number of OTUs was not significant $(t=2.384, p=0.121)$. 


\subsection{NMDS Analysis}

As shown in Figure 4, the samples with different cultivation years clustered separately in the NMDS analysis, and the points representing samples $Y 4$ and $Y 5$ were far from the other samples, indicating that the rhizospheric fungal communities of $Y 4$ and $\mathrm{Y} 5$ were significantly different from the others (Figure 4). Adonis results showed significant differences in rhizospheric fungal communities between $Y 1$ and $Y 3, Y 2$ and $Y 3, Y 3$ and $Y 5$ and $Y 4$ and $Y 5\left(R^{2}=0.639,0.558,0.590\right.$ and 0.511 , respectively, $p=0.001$; Table 4$)$, reflected that the fungal community structure in Y 5 was clearly different from those in the other samples.

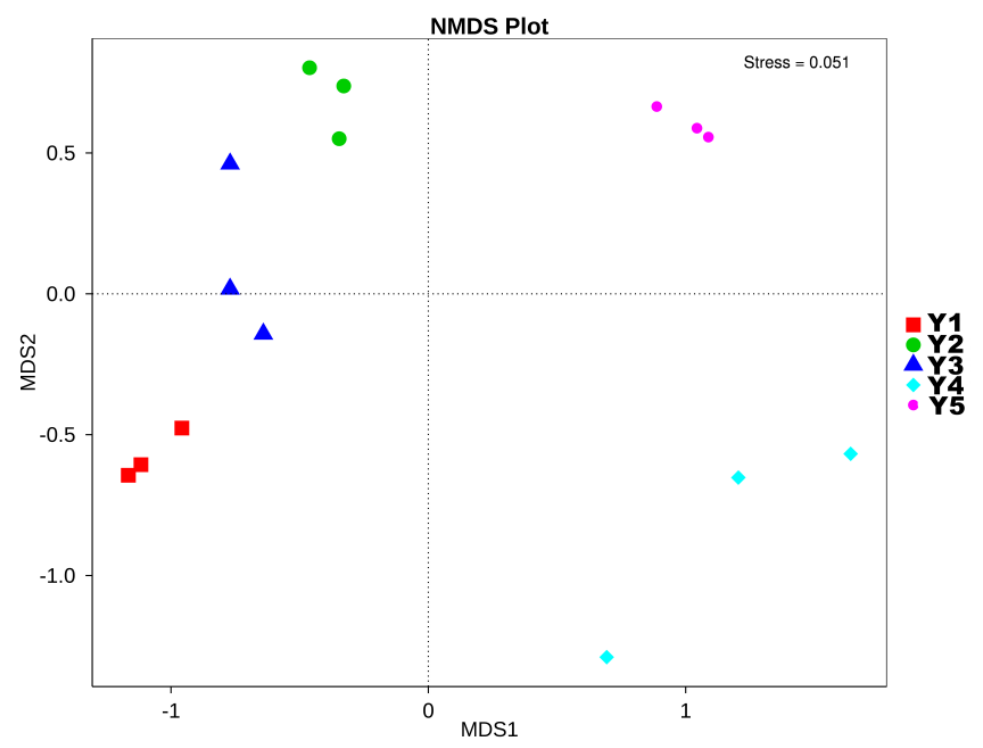

Figure 4. NMDS based on Bray-Curtis dissimilarities at the gene level (stress $=0.051$ ). The differences between the samples or the groups were expressed by the distance in the figure, and the nearer distance showed the more similar fungal community structure between the two samples. NMDS can accurately reflect the difference between samples when Stress < 0.2. Y1-Y5: F. taipaiensis rhizospheric soils with different cultivation years from 1 to 5 .

Table 4. Adonis analysis between groups.

\begin{tabular}{ccccccc}
\hline Vs Groups & Df & Sums of Sqs & Mean Sqs & F. Model & $\mathbf{R}^{\mathbf{2}}$ & $p$ \\
\hline Y1/Y2 & 1 & 1.026 & 1.026 & 22.382 & 0.848 & 0.100 \\
Y1/Y3 & 1 & 0.723 & 0.723 & 7.076 & 0.639 & 0.001 \\
Y1/Y4 & 1 & 1.162 & 1.162 & 12.104 & 0.752 & 0.100 \\
Y1/Y5 & 1 & 1.131 & 1.131 & 19.166 & 0.827 & 0.100 \\
Y2/Y3 & 1 & 0.581 & 0.581 & 5.050 & 0.558 & 0.001 \\
Y2/Y4 & 1 & 0.566 & 0.566 & 5.194 & 0.565 & 0.100 \\
Y2/Y5 & 1 & 0.495 & 0.495 & 6.871 & 0.632 & 0.100 \\
Y3/Y4 & 1 & 0.728 & 0.728 & 4.407 & 0.524 & 0.100 \\
Y3/Y5 & 1 & 0.738 & 0.738 & 5.754 & 0.590 & 0.001 \\
Y4/Y5 & 1 & 0.510 & 0.510 & 4.175 & 0.511 & 0.001 \\
\hline
\end{tabular}

\subsection{Soil Biochemical Analysis}

As shown in Table 5, the $\mathrm{pH}$ of the rhizospheric soil decreased after an initial increase with the cultivation year: change from Y1 sample's weak acidity to Y4 sample's weak alkalinity and then slightly declined in Y5. The organic matter content in the samples declined with the cultivation year, indicating that microorganisms in F. taipaiensis rhizospheric soil dissolved the organic matter. The content of available phosphorus showed a decline with the cultivation year, which corresponded to the gradual decrease in phosphatase activity. 
Table 5. Soil biochemical analysis along five years of F. taipaiensis cultivation.

\begin{tabular}{lccccc}
\hline \multirow{2}{*}{$\begin{array}{l}\text { Anzyme } \\
\text { Activity/Content/pH }\end{array}$} & \multicolumn{5}{c}{ Samples } \\
\cline { 2 - 6 } & $\mathbf{Y 1}$ & $\mathbf{Y 2}$ & $\mathbf{Y 3}$ & $\mathbf{Y 4}$ & $\mathbf{Y 5}$ \\
\hline $\mathrm{pH}$ & $6.43 \mathrm{c}$ & $6.50 \mathrm{c}$ & $6.52 \mathrm{c}$ & $7.47 \mathrm{a}$ & $6.85 \mathrm{~b}$ \\
Enzyme activity/content & & & $\mathrm{g} / \mathrm{kg}$ & & \\
Acid phosphatase & $0.728 \mathrm{a}$ & $0.577 \mathrm{ab}$ & $0.473 \mathrm{~b}$ & $0.441 \mathrm{~b}$ & $0.683 \mathrm{a}$ \\
Alkaline phosphatase & $0.128 \mathrm{a}$ & $0.101 \mathrm{~b}$ & $0.093 \mathrm{bc}$ & $0.078 \mathrm{c}$ & $0.055 \mathrm{~d}$ \\
Catalase & $0.674 \mathrm{a}$ & $0.539 \mathrm{~b}$ & $0.528 \mathrm{~b}$ & $0.677 \mathrm{a}$ & $0.669 \mathrm{a}$ \\
Invertase & $12.815 \mathrm{c}$ & $9.558 \mathrm{~d}$ & $9.239 \mathrm{~d}$ & $21.772 \mathrm{~b}$ & $28.948 \mathrm{a}$ \\
Organic matter & $36.038 \mathrm{a}$ & $28.825 \mathrm{~b}$ & $26.124 \mathrm{~b}$ & $21.423 \mathrm{c}$ & $21.323 \mathrm{c}$ \\
Protease & $0.280 \mathrm{c}$ & $0.270 \mathrm{c}$ & $0.277 \mathrm{c}$ & $0.350 \mathrm{~b}$ & $0.469 \mathrm{a}$ \\
Urease & $5.407 \mathrm{ab}$ & $5.662 \mathrm{a}$ & $5.235 \mathrm{ab}$ & $4.389 \mathrm{c}$ & $4.733 \mathrm{bc}$ \\
& & & $\mathrm{mg} / \mathrm{kg}$ & & \\
Available nitrogen & $112.000 \mathrm{~b}$ & $134.303 \mathrm{a}$ & $113.044 \mathrm{~b}$ & $80.312 \mathrm{c}$ & $78.212 \mathrm{c}$ \\
Available phosphorus & $149.466 \mathrm{a}$ & $95.478 \mathrm{~b}$ & $96.076 \mathrm{~b}$ & $43.716 \mathrm{c}$ & $38.413 \mathrm{~d}$ \\
Available potassium & $404.853 \mathrm{a}$ & $173.790 \mathrm{~d}$ & $209.447 \mathrm{c}$ & $168.293 \mathrm{~d}$ & $301.979 \mathrm{~b}$ \\
\hline
\end{tabular}

Values followed by the same letter in the column do not differ significantly $(p<0.05)$. Y1-Y5: F. taipaiensis rhizospheric soils with different cultivation years from 1 to 5 .

The available potassium content in samples varied greatly with the cultivation year. The content of available nitrogen in sample $\mathrm{Y} 2$ was significantly higher than that in sample $\mathrm{Y} 1$ and then declined with the cultivation year, showing a changing trend similar to the urease activity. The protease activities in $Y 1, Y 2$ and $Y 3$ samples did not show any significant difference and then rose in the $Y 4$ and $Y 5$ samples. The invertase activity in samples $\mathrm{Y} 2$ and $\mathrm{Y} 3$ were lower than that in sample $\mathrm{Y} 1$ but then apparently increased in samples Y4 and Y5. The catalase activity in the samples also increased after an initial decrease with the cultivation year.

\subsection{Correlation Analysis}

A correlation was established among the soil factors by SPSS 22.0: $\mathrm{pH}$ was negatively correlated with the content of available phosphorus, available nitrogen, and the activity of urease and positively correlated with the activity of invertase $(p<0.05)$. The activity of acid phosphatase was significantly positively correlated with the content of available potassium $(p<0.01)$. The activity of alkaline phosphatase was significantly positively correlated with the content of available phosphorus and organic matter, significantly negatively correlated with the activity of protease $(p<0.01)$, positively correlated with the content of available nitrogen and the activity of urease, and negatively correlated with the activity of invertase $(p<0.05)$.

The activity of catalase was positively correlated with the activity of invertase and negatively correlated with the content of available nitrogen $(p<0.05)$. The activity of invertase was significantly positively correlated with the activity of protease, significantly negatively correlated with the activity of urease and the content of available nitrogen $(p<0.01)$ and negatively correlated with the content of available phosphorus and organic matter $(p<0.05)$.

The content of organic matter was significantly positively correlated with the content of available phosphorus $(p<0.01)$, positive correlated with the activity of urease and the content of available nitrogen, and negatively correlated with the activity of protease $(p<0.05)$. The activity of protease was significantly negatively correlated with the content of available nitrogen. The content of available phosphorus was positive correlated with the activity of urease and the content of available nitrogen $(p<0.05)$. The activity of urease was significantly positively correlated with the content of available nitrogen $(p<0.01)$ (Table 6). 
Table 6. Correlation analysis of the biochemical factors in the rhizospheric soil with different cultivation years.

\begin{tabular}{|c|c|c|c|c|c|c|c|c|c|c|}
\hline & $\mathrm{pH}$ & $\begin{array}{l}\text { Acid Phos- } \\
\text { phatase }\end{array}$ & $\begin{array}{l}\text { Alkaline } \\
\text { Phos- } \\
\text { phatase }\end{array}$ & Catalase & Invertase & $\begin{array}{l}\text { Organic } \\
\text { Matter }\end{array}$ & Protease & Urease & $\begin{array}{l}\text { Available } \\
\text { Nitrogen }\end{array}$ & $\begin{array}{l}\text { Available } \\
\text { Phospho- } \\
\text { rus }\end{array}$ \\
\hline $\begin{array}{l}\text { Available } \\
\text { potassium }\end{array}$ & -0.429 & $0.870^{* *}$ & 0.372 & 0.522 & 0.135 & 0.592 & 0.134 & 0.184 & -0.087 & 0.528 \\
\hline $\begin{array}{l}\text { Available } \\
\text { phosphorus }\end{array}$ & $-0.766^{*}$ & 0.405 & $0.959^{* *}$ & -0.217 & $-0.758^{*}$ & 0.980 ** & -0.763 & $0.784^{*}$ & $0.716^{*}$ & \\
\hline $\begin{array}{l}\text { Available } \\
\text { nitrogen }\end{array}$ & $-0.770^{*}$ & 0.063 & $0.715 *$ & $-0.745^{*}$ & $-0.911^{* *}$ & $0.681 *$ & $-0.835^{* *}$ & 0.950 ** & & \\
\hline Urease & -0.917 * & 0.348 & $0.709 *$ & -0.631 & $-0.805^{* *}$ & $0.771 *$ & -0.695 & & & \\
\hline Protease & 0.489 & 0.235 & $-0.859 * *$ & 0.557 & $0.967^{* *}$ & $-0.686^{*}$ & & & & \\
\hline Organic matter & -0.733 & 0.527 & $0.949^{* *}$ & -0.095 & $-0.664 *$ & & & & & \\
\hline $\begin{array}{l}\text { Invertase } \\
\text { Catalase }\end{array}$ & $\begin{array}{l}0.646^{*} \\
0.529\end{array}$ & $\begin{array}{l}0.185 \\
0.394\end{array}$ & $\begin{array}{l}-0.789 * \\
-0.180\end{array}$ & $0.734 *$ & & & & & & \\
\hline $\begin{array}{l}\text { Alkaline } \\
\text { phosphatase }\end{array}$ & -0.593 & 0.244 & & & & & & & & \\
\hline $\begin{array}{l}\text { Acid } \\
\text { phosphatase }\end{array}$ & -0.514 & & & & & & & & & \\
\hline
\end{tabular}

"**: $p<0.05, "$ "**": $p<0.01$.

\subsection{Relationship between the Rhizospheric Fungal Community and the Soil Biochemical Factors}

As shown in Figure 5, the soil-chemical factors contributed $86.86 \%$ of the total characteristic value that affect the fungal community in the $F$. taipaiensis rhizospheric soils with different cultivation years. The $\mathrm{pH}\left(\mathrm{R}^{2}=0.8735, p=0.001\right)$, the urease activity $\left(\mathrm{R}^{2}=0.8652\right.$, $p=0.001)$, the content of available phosphorus $\left(R^{2}=0.7913, p=0.001\right)$ and the content of organic matter $\left(R^{2}=0.8437, p=0.001\right)$ were the dominate factors to affect the rhizospheric soil fungal community structure, among which the $\mathrm{pH}$ was the most influential factor.

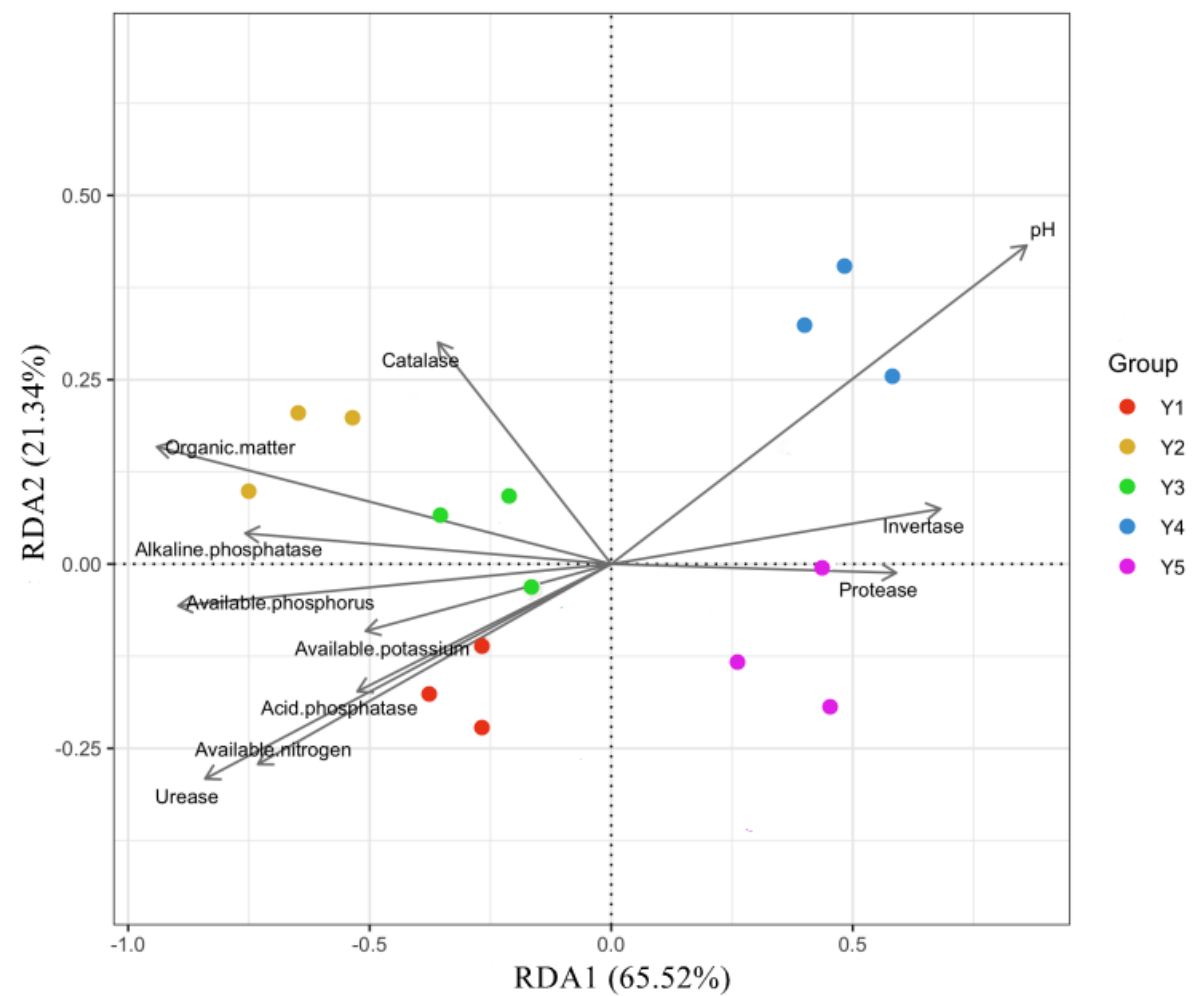

Figure 5. $\mathrm{db}-\mathrm{RDA}$ on fungal communities and soil biochemical factors. Acid phosphatase: activity of acid phosphatase; Alkaline phosphatase: activity of alkaline phosphatase; Catalase: activity of catalase; Invertase: activity of invertase; Organic matter: content of organic matter; Protease: activity of protease; Urease: activity of urease; Available nitrogen: content of available nitrogen; Available phosphorus: content of available phosphorus; and Available potassium: content of available potassium. 


\section{Discussion}

\subsection{Cultivation Year Changed the Fungal Alpha Diversity in the F. taipaiensis Rhizosphere}

The richness and the composition of a microbial community are important for the quality, structure and ecosystem balance of soil [28]. Previous studies found that the ACE and Shannon indices of the fungi community in the rhizosphere of Chinese medicinal herbs declined continuously with the increasing cultivation year, indicating a decrease in the species richness and evenness [29]. In this study, the Chao1 and ACE indices of the fungal communities in rhizospheric soils of $F$. taipaiensis showed a declining trend with the cultivation year (Table 1), which indicated a decrease in the fungal species richness with the increase in cultivation year.

However, it must be noted that, the Chao1 and ACE indices showed an upward trend from Y2 to Y4. The reason may be the fertilization during the cultivation. Previous studies showed the fertilization can increase the richness of rhizospheric fungi [30-32]. Moreover, the sample $\mathrm{Y} 4$ had the highest Chao1 and ACE indices, indicating the maximal fungal species richness, which was consistent with the results in the Venn diagram (Figure $3 b$ ) and the clustering and NMDS (Figures 2 and 4 ) analysis: the rhizospheric soil with 4 years of cultivation had the most unique OTUs and its fungal community composition was different from the other samples.

On the other hand, researchers found that plants can shape their rhizosphere microbiome by root exudates [33], which explained the enormous decrease of Chao1 and ACE in Y5 compared with Y4. On the other hand, no significant difference was detected between the Shannon and Simpson indices of the samples, which did not indicate any obvious change on the uniformity of the fungal species in the samples with different cultivation years.

The "core community" is a relatively stable microbial group in the rhizosphere of a plant, which is less influenced by the external factors [34]. In this study, we found the effect of cultivation year on the OTUs number of the core community contain 13 genera was not significant, indicating the "core community" in F. taipaiensis rhizosphere was more stable than the total fungal community.

This result is similar to the previous study on the effect of cultivar-level genotype difference on the lettuce phyllosphere fungal communities [35]. However, the change on the composition of the total fungal community may lead to an imbalance of microbial community structure in F. taipaiensis rhizosphere.

\subsection{Pathogenic Fungi Accumulated in the F. taipaiensis Rhizosphere with the Cultivation Year}

Continuous cropping is considered as a process of disease accumulation [36]. In this study, the dominant genera in sample Y1 were mainly the flora that can degrade cellulose and promote the organic cycling in soil and the flora that produce secondary metabolites to protect plants from diseases or promote the growth of plants (Table 2, Figure 3a): Pseudogymnoascus, Crustoderma, Mariannaea, Aquamyces, Arthrobotrys, Trichocladium and Nowakowskiella are saprophytic fungi widely distributed in the soil that can degrade cellulose to increase the soil organic matter content [37-39].

Sarocladium is also known to produce antimicrobial secondary metabolites, such as helvolic acid and cerulenin, which protect the plants from pathogens [40]. Trichoderma is an antagonistic fungus to pathogen Fusarium that promotes the growth of plants [41]. Arthrobotrys also preys on nematode under the induction conditions [39]. Phialocephala is an endophytic fungus that coexists with plants and produce mycorrhiza [42]. Moreover, Mariannaea has been previously described as a pathogen of insects that protects the plants from the harm of insects [37].

With the increase in cultivation year, the genera that contain pathogens began to be accumulated as the dominant fungal groups in the rhizospheric soils of $F$. taipaiensis, which cause an imbalance in the soil microbial community diversity and structure. For the dominant fungal groups of sample Y2: Monographella causes the leaf-scald disease of rice [43]. Colletotrichum species are widespread phytopathogens causing anthracnose foliar 
blight or fruit and stem rot on more than 3000 plant species, generating large economic losses on crops, vegetables and fruit trees worldwide [44].

Ustilago species are ubiquitous pathogens that can cause dark brown to black linear sori of varying length in the leaves of grasses [45]; most species of Myrothecium are saprophytes but some are expressive plant pathogens hat can cause leaf spots [46]. Hymenoscyphus are pathogens of ash dieback [47]. In sample Y3, the relative abundances of Fusarium and Gibberella increased by 2.03 and 5.40 times, respectively, compared to those in sample Y1.

Some species in the two genera were major plant pathogens that could cause multiple rot diseases, such as wilt, leaf rot, stem rot, ear rot and root rot [48]. For sample Y4, Volutella is a facultative plant pathogen and saprophytes, which causes leaf blight and stem canker in many kinds of plants [49]. In the dominant fungal groups of sample Y5, Heydenia is a pathogen that causes olive knot disease by interaction with the bacteria Pseudomonas savastanoi [50].

\subsection{Analysis on the Effect of Cultivation Years on the Biochemical Factors in the F. taipaiensis rhizosphere}

Some studies showed that the relative abundance of bacteria in the cultivated soil declined while the relative abundance of fungi rose, and the soil microbial population type is converted from bacterial type to fungal type [34]. Another previous study showed that the number of culturable bacteria, inorganic phosphate solubilizing bacteria, organic phosphate solubilizing bacteria, and the bacteria/fungi ratio in the rhizospheric soil of $F$. taipaiensis decline with the increasing cultivation year [10]. Moreover, the bacteria that declined in the abundance included various kinds of nitrogen-fixing bacteria, potash-dissolving bacteria and phosphate-dissolving bacteria [34]. Therefore, the above findings may be the reason for the declining trend of the available nitrogen, phosphorus and potassium contents and the phosphatase and urease activities with increasing cultivation year.

The content of organic matter was negatively correlated with the activity of invertase and positively correlated with the activity of urease, which was consistent with the findings of Zhang et al. [51]. Thus, the changing trend of urease activity in the rhizospheric soil of $F$. taipaiensis in this study was consist with that of organic matter content. The acid phosphatase activity showed an increasing trend after an initial decline with the cultivation year, this phenomenon was opposite to the altered trend of $\mathrm{pH}$, which was consistent with Turner [52].

The reason for the invertase activity showed a trend of decline from sample Y1 to sample $Y 3$ and then significantly increased in samples $Y 4$ and $Y 5$ could be the increase in relative abundance of some saprophytic fungi, which were also plant pathogens [34]. It is difficult to explain why the catalase activity declined from sample $Y 1$ to sample $\mathrm{Y} 3$ and then increase in sample Y4 and Y5. However, the results of the previous study showed that might be due to the accumulation of heavy metal in the rhizospheric soil during the planting [53].

Previous studies have confirmed $\mathrm{pH}$ is one of the most important factors affecting the soil fungal community structure [54]. In this study, the explanation degree of $\mathrm{pH}$ exceeded $80 \%$, which was the most significant among the physical and chemical factors affecting the soil fungal community structure. However, other studies found the dominant factors that influence the microbial communication were varied with different plants [31,55-57].

Moreover, the result of soil microbial community analysis could be influenced by the soil texture [58], season [59], temperature, precipitation [60] and soil depth [61] of the sampling site. While the studies before also showed that the content of available phosphorus plays an important role in soil fungal community structure [54], our study was consist with this conclusion.

The correlation analysis showed a significant correlation was established between rhizospheric soil nutrients and soil enzyme activities. Therefore, the most appropriate fertilization scheme could be formulated according to the promoting or inhibition between the soil factors. Thus, increasing or decreasing the effects of certain soil factors according 
to the degree of relevance can elevate the indices of soil factors to improve the yield and quality of F. taipaiensis.

In addition, during the process of long-term single planting pattern, the plant would release a large number of secondary metabolites, and litter falls into the soil, which would have toxic effects on plants and affect the soil microbial structure [62]. In the actual production, the production cycle of F. taipaiensis is long and mainly begins as seed sowing, which usually needs at least 5 years from germination to harvest [63], and the secondary metabolites produced during the growth might adversely affect the quality of $F$. taipaiensis.

\section{Conclusions}

Long-term single planting changed the fungal community structure in F. taipaiensis rhizospheric soil, and the decline in the richness of the soil fungal community led to an imbalance of the soil microbial structure. The relative abundance of beneficial fungi decreased, and pathogenic fungi accumulated. The rising soil $\mathrm{pH}$ was not suitable for $F$. taipaiensis growth. The decrease of available nitrogen, available phosphorus and organic matter impoverished the soil. All the above factors would not be conducive to the sustainable production of $F$. taipaiensis. To resolve the germplasm decline that appeared in the production of $F$. taipaiensis, a comprehensive approach that combined organic and biofertilizer with a reasonable rotation would be a promising future development direction.

Supplementary Materials: The following are available online at https:/ / www.mdpi.com/article/10 .3390/horticulturae7120560/s1, Table S1: Species represent the common OTUs.

Author Contributions: Conceptualization, N.Z., Y.Z. and W.L.; methodology, N.Z. and W.L.; software, M.M.; validation, N.Z., Y.Z. and M.M.; formal analysis, N.Z.; investigation, M.M. and Y.Z.; resources, W.L., H.X. and Y.W.; data curation, Y.W.; writing-original draft preparation, N.Z. and Y.Z.; writing-review and editing, Y.Z. and W.L.; visualization, Y.Z.; supervision, M.M.; project administration, W.L.; funding acquisition, N.Z., Y.Z. and W.L. All authors have read and agreed to the published version of the manuscript.

Funding: This research was funded by basic project of Chongqing Municipal Education Commission (KJQN202101231), key project of Chongqing Municipal Education Commission (KJZD-K202101201) and Chongqing Natural Science Foundation Project (cstc2021jcyj-msxmX0115).

Institutional Review Board Statement: Not applicable.

Informed Consent Statement: Not applicable.

Data Availability Statement: All obtained sequences data and the raw data of the analysis can be downloaded at https:/ / pan.baidu.com/s/1Pt4YmpQnAZeBBPN_3igsgg (1 December 2021) by the download password of fxv4.

Acknowledgments: We wish to thank Hua Zhang (Chongqing Three Gorges University), Dongqin Guo (Chongqing Three Gorges University) for critical reading and expertise on the analysis.

Conflicts of Interest: The authors declare that they have no conflict of interest.

\section{References}

1. Wang, D.D.; Wang, S.; Chen, X.; Xu, X.L.; Zhu, J.Y.; Nie, L.H. Antitussive, expectorant and anti-inflammatory activities of four alkaloids isolated from Bulbus of Fritillaria wabuensis. J. Ethnopharmacol. 2000, 139, 189-193. [CrossRef]

2. Tan, S.F.; Liu, C.F.; Wang, C.S.; Wang, D.H.; Zhang, Y.Q.; Lin, N. Evaluation on the effect of analgesia and expectorant of Aconiti Radix Cocta in coordination with Fritillaria cirrhosa and Fritillaria thunbergii based on the uniform design method. China J. Chin. Mater. Med. 2013, 38, 2706. [CrossRef]

3. Chen, Z.; Zhang, M. Suitable Technology for Production and Processing of Fritillaria cirrhosa, 1st ed.; China Medical Press: Beijing, China, 2018; p. 8.

4. Li, P.; Xu, G.J. Studies on resources of Chinese drugs Beimu. J. Plant Resour. Environ. 1993, 2, $12-17$.

5. Chinese Pharmacopoeia Commission. Chuanbeimu. In Pharmacopoeia of the People's Republic of China, 1st ed.; Zhao, Y.Y., Fan, Z.X., Huang, K., Li, Z., Gao, Y.M., Eds.; China Medical Science Press: Beijing, China, 2015; p. 36.

6. Duan, B.Z.; Chen, X.L.; Huang, L.F.; Lu, Q.F.; Li, X.W.; Chen, S.L. A survey of resource science of Fritillaria Taipaiensis. Mod. Chin. Med. 2010, 12, 12. [CrossRef] 
7. Jiang, S.Y.; Sun, H.B.; Qin, J.H.; Zhu, W.T.; Sun, H. Functional production regionalization for Fritillariae Cirrhosae bulbs based on growth and quality suitability assessment. China. J. Chin. Mater. Med. 2016, 41, 3194. [CrossRef]

8. Duan, B.Z.; Huang, L.F.; Yu, Y.L.; Wang, L.Z.; Xie, C.X.; Suo, F.M. Regionalization for growing Fritillaria taipaiensis P. Y. Li by TCMGIS-II. World Sci. Technol./Mod. Tradit. Chin. Medic. Mater. Med. 2010, 12, 486-488. [CrossRef]

9. Gu, W.C.; Mu, M.J.; Yang, M.; Guo, D.Q.; Zhou, N. Correlation analysis between bulb quality and rhizosphere soil factors of Fritillaria taipaiensis. Chin. J. Exp. Tradit. Med. Form. 2020, 26, 165-177. [CrossRef]

10. Mu, M.J.; Zhang, D.G.; Zhang, H.; Yang, M.; Guo, D.Q.; Zhou, N. Correlation between rhizospheric microorganisms distribution and alkaloid content of Fritillaria taipaiensis. China J. Chin. Mater. Med. 2019, 44, 2231-2235. [CrossRef]

11. Peng, R.; Ma, P.; Mo, R.Y.; Sun, N.X. Analysis of the bioactive components from different growth stages of Fritillaria taipaiensis P. Y. Li. Acta Pharm. Sin. 2013, 3, 167-173. [CrossRef]

12. Nannipieri, P.; Kandeler, E.; Ruggiero, P.; Burns, R.G.; Dick, R.P. Enzymes in the Environment: Activity, Ecology and Applications, 1st ed.; Marcel Dekker: New York, NY, USA, 2002.

13. Sparling, G.P. Biological Indicators of Soil Health, 1st ed.; CAB International: Wallingford, UK, 1997.

14. Alkorta, I.; Aizpurua, A.; Riga, P.; Albizu, I.; Amezaga, I.; Garbisu, C. Soil enzyme activities as biological indicators of soil health Rev. Environ. Health 2003, 18, 65-73. [CrossRef]

15. Lu, L.H.; Yin, S.X.; Liu, X.; Zhang, W.M.; Gu, T.Y.; Shen, Q.R. Fungal networks in yield-invigorating and debilitating soils induced by prolonged potato monoculture. Soil Biol. Biochem. 2013, 65, 186-194. [CrossRef]

16. Sun, J.; Zhang, Q.; Zhou, J.; Wei, Q.P. Illumina amplicon sequencing of $16 \mathrm{~S}$ rRNA Tag reveals bacterial community development in the rhizosphere of apple nurseries at a replant disease site and a new planting site. PLoS ONE 2014, 9, e111744. [CrossRef]

17. Yao, H.Y.; Jiao, X.D.; Wu, F.Z. Effects of continuous cucumber cropping and alternative rotations under protected cultivation on soil microbial community diversity. Plant Soil 2006, 284, 195-203. [CrossRef]

18. Chen, M.N.; Li, X.; Yang, Q.L.; Chi, X.Y.; Pan, L.J.; Chen, N. Soil eukaryotic microorganism succession as affected by continuous cropping of peanut-pathogenic and beneficial fungi were selected. PLoS ONE 2012, 7, e40659. [CrossRef]

19. Xiong, W.; Li, Z.G.; Liu, H.J.; Xue, C.; Zhang, R.F.; Wu, H.S. The Effect of Long-Term Continuous Cropping of Black Pepper on Soil Bacterial Communities as Determined by 454 Pyrosequencing. PLoS ONE 2015, 10, e0136946. [CrossRef]

20. Zhang, Z.Y.; Yang, W.X.; Chen, Y.H.; Chen, X.J. Effects of consecutively monocultured Rehmannia glutinosa L. on diversity of fungal community in rhizospheric soil. J. Integr.Agr. 2011, 10, 1374-1384. [CrossRef]

21. Zhou, X.; Wu, F. Dynamics of the diversity of fungal and Fusarium communities during continuous cropping of cucumber in the greenhouse. FEMS Microbiol. Ecol. 2012, 80, 469-478. [CrossRef] [PubMed]

22. Zhou, X.J.; Yang, Y.X.; Hu, P.; Zhang, M.; Xia, Y.L. Investigation on the resources of Fritillaria taipaiensis. J. Anhui. Agric. Sci. 2015, 43, 84-85. [CrossRef]

23. Wu, Z.Z.; Wu, C.S. Effects of different fertilization modes on the growth of Fritillaria taipaiensis. Agric. Eng. 2016, 6, 153-154. [CrossRef]

24. Hernández, M.; Calabi, M.; Conrad, R.; Dumont, M.G. Analysis of the microbial communities in soils of difffferent ages following volcanic eruptions. Pedosphere 2020, 31, 126-134. [CrossRef]

25. Lin, X.G. Principles and Methods of Soil Microbial Research, 1st ed.; Higher Education Press: Beijing, China, 2010.

26. Guan, S.Y. Soil Enzyme and Its Research Method, 1st ed.; Agricultural Press: Beijing, China, 1986.

27. Cai, L.T.; Hu, Z.Y.; Luo, Z.Y. Extraction of total DNA of microbes from tobacco diseased-field soil by SDS-CTAB method. Acta Agric. Jiangxi 2011, 44, 641-670. [CrossRef]

28. Kennedy, A.C.; Smith, K.L. Soil microbial diversity and the sustainability of agricultural soils. Plant Soil 1995, 170, 75-86. [CrossRef]

29. Song, X.; Pan, Y.; Li, L.; Wu, X.; Wang, Y. Composition and diversity of rhizosphere fungal community in Coptis chinensis Franch. continuous cropping fields. PLoS ONE 2018, 13, e0193811. [CrossRef]

30. Wen, Y.C.; Li, H.Y.; Lin, Z.A.; Zhao, B.Q.; Sun, Z.B.; Yuan, L. Long-term fertilization alters soil properties and fungal community composition in fuvo-aquic soil of the North China Plain. Sci. Rep. 2020, 10, 7198. [CrossRef]

31. Wang, S.N.; Cheng, J.K.; Li, T.; Liao, Y.C. Response of soil fungal communities to continuous cropping of fue-cured tobacco. Sci. Rep. 2020, 10, 19911. [CrossRef] [PubMed]

32. Sun, R.; Dsouza, M.; Gilbert, J.A.; Guo, X.S.; Wang, D.Z.; Guo, Z.B. Fungal community composition in soils subjected to long-term chemical fertilization is most influenced by the type of organic matter. Environ. Microbiol. 2016, 18, 5137-5150. [CrossRef] [PubMed]

33. Olanrewaju, O.S.; Ayangbenro, A.S.; Glick, B.R.; Babalola, O.O. Plant health: Feedback effect of root exudates-rhizobiome interactions. Appl. Microbiol. Biotechnol. 2019, 103, 1155-1166. [CrossRef] [PubMed]

34. Haelewaters, D.; Urbina, H.; Brown, S.; Newerth-Henson, S.; Aime, M.C. Isolation and molecular characterization of the Romaine lettuce phylloplane mycobiome. J. Fungi 2021, 7, 227. [CrossRef] [PubMed]

35. Hunter, P.J.; Pink, D.A.C.; Bending, G.D. Cultivar-level genotype differences inflfluence diversity and composition of lettuce (Lactuca sp.) phyllosphere fungal communities. Fungal Ecol. 2015, 17, 183-187. [CrossRef]

36. Haynes, K.M.; Preston, M.D.; McLaughlin, J.W.; Webster, K.; Basiliko, N. Dissimilar bacterial and fungal decomposer communities across rich to poor fen peatlands exhibit functional redundancy. Can. J. Soil Sci. 2015, 95, 219-230. [CrossRef] 
37. Liu, H.; Skinner, M.; Parker, B.L.; Brownbridge, M. Pathogenicity of Beauveria bassiana, Metarhizium anisopliae (Deuteromycotina: Hyphomycetes), and other entomopathogenic fungi against Lygus lineolaris (Hemiptera: Miridae). Brownbridge Source J. Econ. Entomol. 2002, 95, 675-681. [CrossRef]

38. Ortega-Arbulú, A.S.; Pichler, M.; Vuillemin, A.; Orsi, W.D. Effects of organic matter and low oxygen on the mycobenthos in a coastal lagoon. Environ. Microbiol. 2019, 21, 374-388. [CrossRef]

39. Eichorst, S.A.; Kuske, C.R. Identification of cellulose-responsive bacterial and fungal communities in geographically and edaphically different soils by using stable isotope probing. Appl. Environ. Microbiol. 2012, 78, 2316-2327. [CrossRef]

40. Bills, G.F.; Platas, G.; Gams, W. Conspecificity of the cerulenin and helvolic acid producing 'Cephalosporium caerulens', and the hypocrealean fungus Sarocladium oryzae. Mycol. Res. 2004, 108, 1291-1300. [CrossRef]

41. Shoresh, M.; Ilarman, G.E.; Mastouri, F. Induced systemic resistance and plant responses to fungal biocontrol agents. Annu. Rev. Phytopathol. 2010, 48, 21-43. [CrossRef]

42. Lukešová, T.; Kohout, P.; Větrovský, T.; Vohník, M. The Potential of dark septate endophytes to form root symbioses with ectomycorrhizal and ericoid mycorrhizal middle european forest plants. PLoS ONE 2015, 10, e0124752. [CrossRef] [PubMed]

43. Von Arx, J.A. Notes on Monographella and Microdochium. Trans. Br. Mycol. Soc. 1984, 83, 373-374. [CrossRef]

44. O'Connell, R.J.; Thon, M.R.; Hacquard, S.; Amyotte, S.G.; Kleemann, J.; Torres, M.F. Lifestyle transitions in plant pathogenic Colletotrichum fungi deciphered by genome and transcriptome analyses. Nat. Genet. 2012, 44, 1060-1065. [CrossRef] [PubMed]

45. Krus, J.; Dietrich, W.; Zimmermann, H.; Klenke, F.; Richter, U.; Richter, H. Ustilago species causing leaf-stripe smut revisited. IMA Fungus 2018, 9, 49-73. [CrossRef]

46. Quezado-Duval, A.M.; Henz, G.P.; Paz-Lima, M.L.; Medeiros, A.R.; Miranda, B.E.C.; Pfenning, L.H. New hosts of Myrothecium spp. in Brazil and a preliminary In Vitro assay of fungicides. Braz. J. Microbiol. 2010, 41, 246-252. [CrossRef]

47. Han, J.G.; Shrestha, B.; Hosoya, T.; Lee, K.H.; Sung, G.H.; Shin, H.D. First report of the ash dieback pathogen Hymenoscyphus fraxineus in Korea. Mycobiology 2014, 42, 391-396. [CrossRef]

48. Nirenberg, H.I.; O'Donnell, K. New Fusarium species and combinations within the Gibberella fujikuroi species complex. Mycologia 1998, 90, 434-458. [CrossRef]

49. Šafránková, I. Volutella leaf blight and stem canker on Japanese pachysandra in the Czech Republic. Plant Prot. Sci. 2007, 43, 10-12. [CrossRef]

50. Gomes, T.; Pereira, J.A.; Lino-Neto, T.; Bennett, A.E.; Baptista, P. Bacterial disease induced changes in fungal communities of olive tree twigs depend on host genotype. Sci. Rep. 2019, 9, 5882. [CrossRef] [PubMed]

51. Zhang, H.; Zhang, G.L. Microbial biomass carbon and total organic carbon of soils as affected by rubber cultivation. Pedosphere 2003, 13, 535-537. [CrossRef]

52. Turner, B.L. Variation in $\mathrm{pH}$ optima of hydrolytic enzyme activities in tropical rain forest soils. Appl. Environ. Microbiol. 2010, 76, 6485-6493. [CrossRef] [PubMed]

53. Mu, M.J.; Zhou, X.Q.; Guo, D.Q.; Wang, Q.; Yang, M.; Zhang, H.; Zhou, N. Effect of growth years to the soil enzyme activities and heavy metal residue of Fritillaria taipaiensis P. Y. Li. Environ. Chem. 2019, 38, 1966-1972. [CrossRef]

54. Zhang, B.; Liang, C.; He, H.B.; Zhang, X.D. Variations in soil microbial communities and residues along an altitude gradient on the northern slope of changbai mountain, China. PLoS ONE 2013, 8, e66184. [CrossRef]

55. Cleveland, C.C.; Nemergut, D.R.; Schmidt, S.K.; Townsend, A.R. Increases in soil respiration following labile carbon additions linked to rapid shifs in soil microbial community composition. Biogeochemistry 2007, 82, 229-240. [CrossRef]

56. Liu, J.J.; Yu, Z.; Wang, X.; Jin, J.; Liu, X.; Wang, G. Soil carbon content drives the biogeographical distribution of fungal communities in the black soil zone of northeast China. Soil Biol. Biochem. 2015, 83, 29-39. [CrossRef]

57. Li, Y.L.; Tremblay, J.; Bainard, L.D.; Cade-Menun, B.; Hamel, C. Long-term efects of nitrogen and phosphorus fertilization on soil microbial community structure and function under continuous wheat production. Environ. Microbiol. 2019, 22, 1066-1088. [CrossRef]

58. Deng, S.; Ke, T.; Li, L.; Cai, S.; Zhou, Y.; Liu, Y.; Guo, L.; Chen, L.; Zhang, D. Impacts of environmental factors on the whole microbial communities in the rhizosphere of a metal-tolerant plant: Elsholtzia haichowensis Sun. Environ. Pollut. 2018, 237, 1088-1097. [CrossRef]

59. Buée, M.; De Boer, W.; Martin, F.; van Overbeek, L.; Jurkevitch, E. The rhizosphere zoo: An overview of plant-associated communities of microorganisms, including phages, bacteria, archaea, and fungi, and of some of their structuring factors. Plant Soil 2009, 321, 189-212. [CrossRef]

60. Zachow, C.; Berg, C.; Müller, H.; Meincke, R.; Komon-Zelazowska, M.; Druzhinina, I.S.; Kubicek, C.P.; Berg, G. Fungal diversity in the rhizosphere of endemic plant species of Tenerife (Canary Islands): Relationship to vegetation zones and environmental factors. ISME J. 2009, 3, 79-92. [CrossRef]

61. Zhang, T.; Wang, Z.; Lv, X.; Li, Y.; Zhuang, L. High-throughput sequencing reveals the diversity and community structure of rhizosphere fungi of Ferula Sinkiangensis at diferent soil depths. Sci. Rep. 2019, 9, 6558. [CrossRef] [PubMed]

62. Pramanik, M.H.R.; Nagai, M.; Asao, T. Effect of temperature and hotoperiod on the phytotoxic root exudate of cucumber (Cucumis sativus) in hydroponic culture. J. Chem. Ecol. 2000, 28, 1953-1967. [CrossRef]

63. Zhang, Z.Y.; Lin, W.X. Continuous cropping obstacle and allelopathic autotoxicity of medicinal plants. Chin. J. Eco-Agric. 2009, 1, 189-196. [CrossRef] 